Article

\title{
Effect of Forestland Property Rights and Village Off-Farm Environment on Off-Farm Employment in Southern China
}

\author{
Yang Yang ${ }^{1}$, Hua Li ${ }^{2}$, Zhen Liu $\left.{ }^{3}{ }^{(}\right)$, Long Cheng ${ }^{1}$, Assem Abu Hatab ${ }^{4,5}$ and Jing Lan ${ }^{6, *}$ \\ 1 School of Economics and Management, Xi'an University of Posts \& Telecommunications, \\ Xi'an 710121, China; yang.yeah0322@163.com (Y.Y.); ullie_ch@163.com (L.C.) \\ 2 College of Economics and Management, Northwest Agriculture \& Forestry University, \\ Yangling 712100, China; lihua7485@163.com \\ 3 School of Business, Nanjing Normal University, Nanjing 210046, China; zhenliu_cn@yahoo.com \\ 4 Department of Economics, Swedish University of Agricultural Sciences, SE-750 07 Uppsala, Sweden; \\ assem.abouhatab@slu.se \\ 5 Department of Economics and Rural Development, Arish University, Al-Arish 45511, Egypt \\ 6 College of Public Administration, Nanjing Agricultural University, Nanjing 210095, China \\ * Correspondence: lanjinge@yahoo.com
}

Received: 17 February 2020; Accepted: 23 March 2020; Published: 25 March 2020

\begin{abstract}
Reasonably promoting the off-farm employment of rural surplus labor in China's collective forest areas is an important way to increase forest resources and increase farmers' income. China's new round of collective forest tenure reform (CFTR) aims to optimize forest area labor allocation by strengthening forestland property rights. Therefore, in different village off-farm environments, it is necessary to explore how forestland property rights affect off-farm employment in forest areas. Based on survey data from 742 households in Zhejiang and Jiangxi provinces, this paper examines this effect using the double-hurdle model. The results indicate that forestland transfer rights promote decision-making about, and the supply of, off-farm labor, while forest harvesting rights significantly increase the supply of off-farm labor. The villages' off-farm income ratio also affected the supply of off-farm labor. Moreover, under the regulation of the village off-farm income ratio, the positive incentives of forestland transfer rights on decision-making about, and the supply of, off-farm labor gradually weakened, but the incentive effect of forest harvesting rights on the supply of off-farm labor gradually increased. It is proposed that the CFTR should be further promoted, the forestland circulation mechanism and regulating forest harvest quota system should be improved, and implementation of forestry property mortgages should be strengthened.
\end{abstract}

Keywords: collective forest tenure reform; forestland property rights; village off-farm environment; off-farm employment

\section{Introduction}

Accompanying industrialization and urbanization, labor from rural areas has shifted rapidly to the non-agricultural sector, greatly contributing to the development of the economy and society in China [1-3]. In recent years, the number of farmers transferring to the non-agricultural sector is still growing steadily. According to the National Bureau of Statistics, the Chinese rural labor force in cities was 288.36 million in 2018, which is $0.6 \%$ more than the previous year [4]. However, with the constant increases in salaries and the "labor shortage" phenomenon [5], scholars have discussed the approach of the "Lewis inflection point" in China. The collective forest area constitutes a relatively concentrated resource distribution center in China which plays an important role in both economic 
and social development, as well as ecological construction. According to the 9th Forestry Survey in China, the total area of forestland in China encompasses 186 million $\mathrm{hm}^{2}$, accounting for $60.0 \%$ of the total forestland in the country [6].The collective forestland in the south is, for the most part, distributed throughout 10 provinces, including Zhejiang, Jiangxi, Anhui, Fujian, Guangdong, Guangxi, Guizhou, Hunan, Hubei, and Hainan, involving a total population of 543 million people [7]. In the context of the continuous movement trends of rural labor, a large number of young and middle-aged labor in collective southern forest areas turned to urban and off-farm sectors, resulting in scarcity and a decline in the quality of labor supply in the region [8]. For instance, the total number of rural labor forces in cities in Zhejiang Province reached 13.7 million in 2018, accounting for $76.6 \%$ of the province's total rural population [9]. The number of rural, non-agricultural laborers in Jiangxi Province totaled 8.9 million in 2018 , accounting for $43.8 \%$ of the total rural population in the province [10]. As regards collective forest areas, the off-farm employment of rural labor not only directly impacts farmers' growth in income, but also has an effect on the increase in forest area resources through the way farmers manage the forest, which is of great significance to the sustainable development of the forest area. As an important part of China's rural economic institution system, the collective forest tenure reform (CFTR), which started in 2003, represents a drastic change in China's forest management pattern [11]. The CFTR improves forestland property rights by confirming rights and implementing various supportive policies [12-14]. Furthermore, enhanced forestland property rights have changed farmers' job preferences and influenced their decisions about entering the off-farm labor market $[15,16]$. In addition, the village off-farm environment has an influence on the process of land property rights affecting the transfer of labor through individual family income structures [17]. Therefore, an urgent investigation of the theories and empirical propositions about how forestland property rights have affected the off-farm employment following the collective forest tenure reform, and what role the village off-farm environment plays, is required.

There is no consensus about the impact of the arrangement of forestland property rights on off-farm employment. Some researchers suggest that stable and complete land property rights can improve labor transfer [18,19], otherwise it is constrained. For example, Gray [20] analyzed the rural out-migration in southern Ecuadorian Andes and found that the landlessness did not consistently increase out-migration. Valsecchi [21] found that tenure insecurity may cause family members to stay at home to avoid losing their land inheritance in Mexico. With regards to China, Mullan et al. [22] considered that incomplete farmland property rights reduce rural labor's off-farm employment, and this is more obvious on forestland. De La Rupelle et al. [23] also pointed out that the insecure and inalienable land rights is a centripetal force that prevents rural people from leaving agriculture and rural areas. The reason is that under the special land arrangement in China, households will lose their land and land incomes if they stop farming, which will increase the cost of off-farm employment for households and result in farmers choosing diversified management practices in order to avoid a loss in land value [24]. A study by Feng and Heerink [25] showed that this is not significant, even though both land contracts and rights to transfer land have a positive impact on the transfer of labor. However, some research has produced contrasting conclusions. For instance, by exploring the out-migration in Mexico and Thailand, VanWey [26] found that land ownership tends to have a negative effect on out-migration. De Brauw and Mueller [27] found that the absence of land rights promoted migration in Ethiopia. Qiu and Luo [17] also pointed out that China's farmland readjustment contributes to the migration of rural labor away from farms, and farmers might respond to the uncertainty of farmland management rights by planting different crop types in order to further release agricultural labor. Moreover, some literature shows that in villages with a poor land rental market, farmers who think land certification is more important for protecting land tenure would be more involved in the off-farm labor supply, whereas farmers who predict that land will not readjust in the future would be less involved with off-farm employment [28].

The above literature has featured discussions on the impact of land tenure on rural labor off-farm employment, but most of them have focused on farmland tenure impacts on the transfer of rural labor 
and paid little attention to the relationship between forest tenure arrangement and forest area labor transfer after the CFTR, not to mention the impact of forestland property rights on labor transfer from the perspective of the village off-farm environment. Thus, based on an investigation of household data from the collective forest area of Zhejiang and Jiangxi provinces, this paper aims to analyze the impact of both forestland property rights and village off-farm environment on off-farm employment in forest areas and explain how forestland property rights affect rural labor off-farm activity participation, as well as the extent of off-farm labor supply.

The reminder of this paper is as follows: Section 2 presents the literature review; Section 3 shows the econometric model specification; Section 4 provides the data and descriptive statistics; Section 5 reports the estimation results and discussion; Section 6 concludes the findings with policy implications.

\section{Literature Review}

\subsection{Forestland Property Rights and Off-Farm Employment}

As a group of rights, the basic contents of property rights include subjects having the right to use, dispose of, and gain from resources. Complete property rights mean they have exclusive access rights, free disposal rights, and exclusive beneficial rights [29]. However, the positive ecological functions of forests cause forestland tenure to suffer from many constraints and restrictions. For instance, frequent forestland readjustments prevent farmers having their own long-term and secure right to use forestland [22]. The delay in the implementation of supportive policies in the CFTR restricts farm households from freely disposing of forestland, such as transfers, mortgages, and so on [30]. In addition, for the rational management and sustainable use of forests, China began to implement a forest harvest quota system in 1987 [31]. With the continuous advancement of reforms, the harvest policy of commercial forests has been relaxed, but it is still strictly restricted by harvest indicators [32]. The enforcement of the forest logging quota system has not only made forestland disposal rights incomplete, but also directly affected forestland beneficial rights [30]. Therefore, complete forestland tenure is mainly reflected in forestland use rights, mortgage rights, harvesting rights, and so on. According to the existing theory, tenure system arrangements have an impact on the use type and efficiency of resources by giving more rights to rural households [33]. The implementation of CFTR has further strengthened farmers' ownership of forestland tenure, and pushed the implementation of various supportive policies, which have redefined the behavior boundaries within which actors can implement each forestland right and thus give rural households more complete forestland property rights. With the deepening of CFTR, as rational economic people, farmers will allocate dynamic factors more effectively, such as labor force, to maximize revenue by comparative advantages between the agricultural and non-agricultural sectors.

The stable right to use forestland is the foundation for property right owners to make a decision [34]. Some previous studies have discussed the possible impacts of the stable forest property rights on rural labor distribution. Jacoby et al. [35] mentioned that stable and complete forestland use rights can increase farmers' awareness of use rights, which decreases the investment risk in the long-term and helps stimulate incentives for farmers to produce; thus rural households will allocate their labor force in forest management to obtain forest management revenue [16]. However, land not only has a production function, but also the function of social security [36]. Land is the foundation of survival and development for most rural households, generally speaking, and they will not easily give up their own land [37]. Therefore, when forestland use rights are unstable, farmers who engage in the non-agriculture sector may face the risk of losing forestland use rights [21]. While forestland use rights are stable, farmers will have a stable source of social security and farmers can assuredly engage in off-farm production [38]. However, the long-term production process of forests and the large gap between revenues from the agricultural and the non-agricultural sectors, which mean that the stable forestland use rights play a greater role in the social security effect, currently contribute to labor off-farm employment. 
Forestland transfer rights are the right for farmers to act independently and transfer forestland without the intervention of other parties. An improvement in forestland transfer rights increases farmers' awareness of transfer rights, which allows farmers to transfer forestland freely; therefore, those farmers willing to engage in the non-agricultural sector and be released from forestland management can allocate more time to non-agricultural production [22]. Moreover, complete forestland transfer rights mean farmers can recover the forestland investment return through forestland transactions when they engage in off-farm employment [39], which further promotes the off-farm transfer of forest labor. Forestland mortgage rights are the rights for farmers to act on their own to mortgage forestland or trees [40]. The mortgage provides a way for farmers to keep forestland while obtaining capital for production at the same time [41]. Therefore, under the complete mortgage right, in order to obtain loans from mortgaged forestland, farmers allocate work time on forest management to promote the forestland mortgage value, which leads farmers to engage in forest production.

Cutting woods is the necessary method for farmers to obtain an income from forests [42]. Farmers find it hard to earn forestland management income with restricted harvesting rights, which means they are unable to manage forest production in line with the goal of maximizing revenue, which reduces the farmers' confidence in forest production and causes many laborers to enter the non-agricultural sector. However, the complete harvesting rights can increase farmers' awareness of harvesting rights, which means that farmers can easily achieve the wood harvest indicator (i.e., when the woods reach cutting age, farmers can apply for, and receive approval for, the harvest indicator from the forest department) [43]. The benefit of this is to raise farmers' expectations about future forest revenues, stimulate farmer productivity, and make farmers spend more time on their forests, restraining the transfer of labor to the non-agricultural sector.

\subsection{Village Off-Farm Environment Adjustment Effect on Forestland Property Rights}

In villages, farmers' behavioral decisions are affected by the surrounding environment [44]. Farmers' interactions within the village affect their perceptions through demonstration, and further affect their decision-making behaviors. The village off-farm environment can be measured by the average of the proportion of farmers' off-farm revenue within the village. Therefore, in the same village, when the farmers' off-farm income accounts for a relatively high proportion of total household income, the relatively fixed and single social network in the village means information spreads quickly in the village, which promotes the off-farm employment from a single farmer household. With the elimination of employment barriers between cities and villages in China, and the increase in forest production opportunity costs, the village off-farm environment plays an important adjustment role when forestland property rights have an impact on off-farm employment by affecting farms' household off-farm income [17]. As analyzed above, farmers compare the revenue between the agricultural and non-agricultural sectors and allocate labor resources more effectively to maximize family revenue [45]. When the off-farm revenue proportion within the village increases, the off-farm revenue proportion in single farmer households also increases. Therefore, the importance of forestland management revenue decreases and farmers' dependence on forest management will also decrease. At the moment, complete forestland property rights have no appeal for farmers [46]. However, even though incomplete forestland property rights restrict off-farm employment, the degree of restriction will decrease, and farmers will prefer the non-agricultural sector with its higher returns.

\section{Econometric Model Specification}

\subsection{Model Specification}

Off-farm employment can be divided into two stages: i) whether farmers decide to participate in off-farm work, and ii) the degree of off-farm labor supply (i.e., the off-farm labor participation model and the off-farm labor supply model) [47]. This paper adopts the double-hurdle model for carrying out estimates, combined with the probit model and truncated model. The double-hurdle model was 
proposed by Cragg, who relaxed the assumptions of the Tobit model, divided individual behavior into two different decision-making stages, and pointed out that these two stages had varying degrees of impact (i.e., these two stages could have different estimated coefficients) [48]. Therefore, this study constructed two stages of off-farm labor supply for rural households in forest areas: in the first stage, a probit model was constructed to estimate whether farmers participate in off-farm work, and in the second stage, the truncated regression model was adopted to analyze the degree of rural households' off-farm labor supply. The specific models of the double-hurdle model were as follows:

$$
\begin{gathered}
\text { First stage: }\left\{\begin{array}{l}
Y_{i 1}^{*}=\alpha X_{i}+\mu_{i}, \mu_{i} \sim N(0,1), i=1,2 \ldots n \\
Y_{i 1}=1, Y_{i 1}^{*}>0, \\
Y_{i 1}=0, Y_{i 1}^{*} \leq 0,
\end{array}\right. \\
\text { Second stage: }\left\{\begin{array}{l}
Y_{i 2}^{*}=\beta Z_{i}+\varepsilon_{i}, \varepsilon_{i} \sim N\left(0, \sigma^{2}\right), i=1,2 \ldots n \\
Y_{i 2}=Y_{i 2}^{*} Y_{i 1}^{*}>0 \text { and } Y_{i 1}=1, \\
Y_{i 2}=0, \text { others }
\end{array}\right.
\end{gathered}
$$

where $Y_{i 1}^{*}$ is the latent variable representing whether farmers have participated in off-farm work. If $Y_{i 1}^{*}>0$, then $Y_{i 1}=1$, which means that farmers participated in off-farm work; if $Y_{i 1}^{*} \leq 0$, then $Y_{i 1}=0$, which means farmers have not participated in off-farm work. $Y_{i 2}^{*}$ is the latent variable representing the degree of off-farm labor supply, $Y_{i 2}$ is the real off-farm labor supply when $Y_{i 1}^{*}>0$ and $Y_{i 1}=1$, $Y_{i 2}=Y_{i 2}^{*} . X_{i}, Z_{i}$ are explanatory variables, and $n$ is the quantity of explanatory variables. $\alpha, \beta$ are the parameters to be estimated, and $\mu_{i}, \varepsilon_{i}$ are the residuals and obey independent normal distribution.

\subsection{Definition of the Variables}

The variables were divided into off-farm employment, forestland property rights, village off-farm environment, and control variables.

Off-farm employment: It can be seen from the above that off-farm labor employment can be divided into whether farmers participated in off-farm work and the degree of off-farm labor supply. The degree of off-farm labor supply can be measured by indices, such as the quantity of off-farm labor supply and its proportion, and the time of non-agricultural labor supply and its proportion. As the quantity and time of off-farm labor supply are stocks, it is hard to identify changes in the degree of the off-farm labor supply based on stocks, while the proportion of off-farm labor time supply is more suitable for measuring the off-farm labor supply condition when the data are reliable [49]. The data used in this paper were highly reliable. Therefore, the proportion of off-farm labor time supply was adopted to represent the degree of off-farm labor supply, which can be calculated by the real off-farm labor time supply of rural households (i.e., the proportion of months engaged in off-farm work out of the total family labor working months).

Forestland property rights: Previous studies show that forestland property rights affect farmers' decision-making behavior by affecting the farmers' subjective perception of tenure [50] (i.e., farmers' recognition of the property rights condition is the basis of farmers' decision-making and behavior) [51]. Thus, from the perspective of farmers' recognition of different property rights, this paper chooses recognition of the right to convert forestland to cropland, the right to change forest type, the right to decide tree species, the right to operate non-timber forest production in the forest, the right to transfer the plot to other villagers, the right to transfer the plot to outsiders, and the right to mortgage forestland certificates and mortgage trees in order to measure farmers' recognition of the forestland property rights condition. With reference to the studies of Holden et al. [52] and Yi et al. [12], with regard to each right, if farmers think they own this right then the value assigned is 4, if they think they should obtain permission from the village or forest department then the value assigned is 3 , if they are uncertain then the value assigned is 2 , and if they think they do not have the right then the value assigned is 1 . With reference to the study of Zhang et al. [53], the weighted average of the right to convert forestland to cropland, the right to change forest type, the right to decide tree species, and the right to operate 
non-timber forest production in the forest were used to represent forestland use rights; the weighted average of the right to transfer the plot to other villagers and the right to transfer the plot to outsiders were used to represent the forestland transfer right; and the weighted average of the right to mortgage forestland certificates and mortgage trees were used to represent forestland mortgage rights. As for forest harvesting rights, under the forest harvest quota system, the only legal way for farmers to own the forest harvesting right is to obtain harvesting indicators [42]; therefore the main index to measure the harvesting right is the difficulty of applying forest harvesting indicators: if farmers think they can easily apply for the harvesting indicators then the value assigned is 3 , if they think it is not too easy to apply for the harvesting indicators then the value assigned is 2 , and if they think that it is difficult then the value assigned is 1 . Moreover, to avoid the endogenous nature of farmers' recognition of forestland property rights, this study referred to the method of Ma et al. [28] and adopted the average recognition on rights of other farmers within the village to replace the level of farmers' recognition on forestland property rights, since recognition of forestland property rights at the village level impacts an individual farmer's recognition, and therefore impacts off-farm employment, while individual farmer labor distribution decisions will not impact other farmers' recognition of forestland property rights [28].

Village off-farm environment: Based on the direct analysis of forestland property rights' effect on off-farm employment, this paper attempts to discuss how the village off-farm environment adjusts the forestland property rights' effect on off-farm employment. As stated above, the average value of off-farm income ratio of village farmers was used to measure the village off-farm environment.

Control variables: The control variables consist of labor characteristics, family characteristics, forestland characteristics, and regional characteristics. In labor characteristics, variables such as the proportion of male labor, the average age of labor, and the average educational level of labor are selected. The higher the proportion of male labor, the more likely it is that rural households will engage in off-farm business [54]; rural households that have an older average age of labor will have less off-farm work because of the lack of ability to work; rural households with a higher average educational level of labor are more willing to engage in off-farm production. The family characteristics include the proportion of the population over 70 years old, the proportion of the population under 16 years old, and whether there was a village cadre in the family. Rural households with more older people are more likely to transfer to off-farm work to gain more revenue as they have a heavier burden of support; rural households with more children are also more likely to engage in off-farm business as they have more educational expenses; rural households that have a village cadre are more likely to participate in off-farm production as they have plenty of social resources [47]. The forestland characteristics consist of forest area and forest plots. Farmers are more willing to manage a larger forest area, which may reduce off-farm work [36]; more forest plots mean a higher level of forestland fragmentation, which will diminish farmer production confidence and impel farmers to engage in off-farm business. The regional characteristics included three county dummy variables (Anji, Suichang, and Chongyi).

\section{Data and Descriptive Statistics}

\subsection{Data Source}

The data used in this paper were from the research group that was conducting a survey of rural households in Zhejiang and Jiangxi provinces in the southern collective forest area of China in 2017. Chinese collective forests are mainly distributed in the southern collective forest area. Of these, Zhejiang and Jiangxi provinces have the greater forest coverage of $59.4 \%$ and $61.2 \%$, respectively [7], and these two provinces are the provinces where the CFTR was implemented earlier. The progress in CFTR, forest development level, and economic development level differ between the two provinces. Since Zhejiang began the CFTR in 2006, it has not only completed the reformative task of clarifying property rights, but it also explored the establishment of a new collective forestry property rights system, a new management system, and a new financial system in order to continually improve 
forestry support and protection. The vitality of collective forestry development has been significantly enhanced, with the level of management considerably improved. In total, $8 \%$ of China's forestry output was produced in Zhejiang, with on $2 \%$ of the country's forestland [55]. Jiangxi issued its reform guidelines in 2004 and began pilot reforms in seven counties, widely launching across the province in 2005. Toward the end of clarifying property rights and reducing attendant taxes and fees, Jiangxi has made the construction of the Forestry Property Rights Trading Center a "leading project", so as to deepen the supporting reforms of the CFTR and standardize the province's forestry service projects and methods, aiming to promote the orderly transfer of woodland resources [56].

Comprehensively considering factors such as forest resource and forest reform characteristics, Anji and Suichang counties in Zhejiang Province, and Chongyi and Suichuan counties in Jiangxi Province were chosen as the investigation areas. These four counties are all key forestry counties in southern China's collective forest area and are the CFTR pilot counties, which have better typicality and representativeness. Anji County is located in northwest Zhejiang Province, which is the birthplace of Chinese Beautiful Village, and its forest coverage was 70.2\% in 2018 [57]. Suichang County is located in southwest Zhejiang, which is the traditional forestry county of Zhejiang Province and had forest coverage of $83.4 \%$ in 2018 [58]. Chongyi County, which is called the "natural oxygen bar", is located in southwest Jiangxi Province, and had forest coverage of $88.3 \%$ in 2018, which is the highest in China's county area [59]. Suichuan county is also located in southwest Jiangxi Province and had forest coverage of $78.8 \%$ in 2018, with the whole county having abundant forest resources [60].

According to the random sampling method, the research group first randomly selected three towns based on the forest resource and economic development condition of the town in every investigation area, then randomly chose four villages in each town, and finally randomly chose 15-20 rural households in every village. The investigation was conducted through one-on-one interviews between the researchers and the farmers on rural household basic information, labor allocation, forestland resource characteristics, forestry production, and forestland property rights. The investigation group sent out 793 questionnaires, after dropping some missing value samples, ultimately producing 766 effective samples. As this paper focuses on the impact of forestland property rights on forest area labor off-farm employment, those samples where the quantities of labor were 0 were eliminated, ultimately producing a sample of 742 rural households.

\subsection{Descriptive Statistics}

The variable descriptive statistics are shown in Table 1. According to Table 1, the proportion of rural households in the sample participating in off-farm work was $89 \%$ and the average of the off-farm labor time supply ratio was $52 \%$, which means that rural households have a higher level of participation in off-farm work. In forestland property rights, the average of use right cognition was 2.33 , the average of transfer right cognition was 3.38, the average of mortgage right cognition was 2.68 , and the average of harvesting right cognition was 2.15, reflecting that rural households have lower cognition on use right and mortgage right, and higher cognition on transfer right and harvesting right. The average proportion of off-farm income in villages was $76 \%$, which means that off-farm income occupies the dominant position in the rural households' income structure. In rural households, male labor was $63 \%$, with 48.68 years as the average age of a laborer. The average educational level of a laborer was 7.54 years, which means more male labor, at an older age, and most have a junior high school education level. The average proportion of the population over 70 years old was $9 \%$, the average proportion of population under 16 years old was $12 \%$, and the average of having a village cadre in the family was $11 \%$. The average forest area was $1.97 \mathrm{hm}^{2}$ and the average number of forest plots was 2.44 , which reflects forestland management of a rural household being of medium size without too many forest plots. 
Table 1. Variable meaning and descriptive statistics.

\begin{tabular}{|c|c|c|c|c|}
\hline Variable & Definition & Abb. & Mean & Std. \\
\hline \multicolumn{5}{|c|}{ Off-farm employment } \\
\hline $\begin{array}{l}\text { Whether to participate in } \\
\text { off-farm work }\end{array}$ & $\mathrm{Yes}=1, \mathrm{No}=0$ & Participate & 0.89 & 0.31 \\
\hline Off-farm labor supply & Labor months of off-farm/labor months of all labor in the family & Supply & 0.52 & 0.29 \\
\hline Use right & $\begin{array}{l}\text { Forestland property rights } \\
\text { Weighted results of cognition of right to convert forestland to } \\
\text { cropland, right to change forest type, right to decide tree species, } \\
\text { right to operate non-timber forest production under the forest }\end{array}$ & Use & 2.33 & 0.89 \\
\hline Transfer right & $\begin{array}{l}\text { Weighted results of cognition of right to transfer plot to other } \\
\text { villagers and transfer plot to outsiders }\end{array}$ & Transfer & 3.38 & 0.90 \\
\hline Mortgage right & $\begin{array}{c}\text { Weighted results of cognition of right to mortgage forestland } \\
\text { certificates and mortgage trees }\end{array}$ & Mortgage & 2.68 & 1.11 \\
\hline Harvesting right & $\begin{array}{l}\text { Cognition of the difficulty of applying for forest harvesting } \\
\text { indicators: difficult }=1 \text {, not too easy }=2 \text {, easy }=3\end{array}$ & Harvesting & 2.15 & 0.75 \\
\hline $\begin{array}{l}\text { Proportion of off-farm } \\
\text { income in village }\end{array}$ & $\begin{array}{l}\text { Village off-farm environment } \\
\text { Average value of off-farm income ratio (off-farm income/total } \\
\text { income) of other households in the same village }\end{array}$ & Income & 0.76 & 0.15 \\
\hline \multicolumn{5}{|c|}{ Labor characteristics } \\
\hline Proportion of male labor & Male labor/total labor force & Male & 0.63 & 0.23 \\
\hline Average age of labor & Average age of labor in family & Age & 48.68 & 9.99 \\
\hline $\begin{array}{l}\text { Average educational } \\
\text { level of labor }\end{array}$ & Average educational level of labor in family & Education & 7.54 & 3.14 \\
\hline \multicolumn{5}{|c|}{ Family characteristics } \\
\hline $\begin{array}{l}\text { Proportion of population } \\
\text { over } 70 \text { years old }\end{array}$ & Family population over 70 years old/total family size & Over 70 & 0.09 & 0.20 \\
\hline $\begin{array}{l}\text { Proportion of population } \\
\text { under } 16 \text { years old }\end{array}$ & Family population under 16 years old/total family size & Under 16 & 0.12 & 0.15 \\
\hline $\begin{array}{l}\text { Whether there is a } \\
\text { village cadre in family }\end{array}$ & Yes $=1, \mathrm{No}=0$ & Cadre & 0.11 & 0.31 \\
\hline \multicolumn{5}{|c|}{ Forestland characteristics } \\
\hline Forest area/hm² & Actual area of family forest & Area & 1.97 & 3.53 \\
\hline Forest plots & Actual number of family forest plots & Plots & 2.44 & 1.45 \\
\hline \multicolumn{5}{|c|}{ Regional characteristics } \\
\hline Anji & Anji $=1$, other $=0$ & Anji & 0.26 & 0.44 \\
\hline Suichang & Suichang $=1$, other $=0$ & Suichang & 0.24 & 0.43 \\
\hline Chongyi & Chongyi $=1$, other $=0$ & Chongyi & 0.25 & 0.43 \\
\hline
\end{tabular}

Table 2 shows the farmers' property rights cognition under different off-farm labor participation statuses. It can be seen that out of 742 rural households, 663 rural households participated in off-farm labor $(89.35 \%)$, and only 79 rural households were not participating in off-farm labor $(10.65 \%)$. In comparison, the average of mortgage right and harvesting right cognition was higher in the rural households participating in off-farm labor than in those not participating in off-farm labor, while the average of use right and transfer right were lower in the rural households participating in off-farm labor than the rural households not participating in off-farm labor. This means that rural households that participate in off-farm labor believe they have a relatively complete forestland mortgage right and harvesting right, but they consider that the use right and transfer right are not complete.

Table 2. Farmers' property rights cognition under different off-farm labor participation statuses.

\begin{tabular}{ccccccc}
\hline \multirow{2}{*}{ Forestland Property Rights } & \multicolumn{3}{c}{ Not Participating } & \multicolumn{3}{c}{ Participating } \\
\cline { 2 - 7 } & Sample Size & Mean & Variance & Sample Size & Mean & Variance \\
\hline Use & 79 & 2.35 & 0.87 & 663 & 2.32 & 0.90 \\
Transfer & 79 & 3.52 & 0.79 & 663 & 3.36 & 0.91 \\
Mortgage & 79 & 2.67 & 1.06 & 663 & 2.69 & 1.12 \\
Harvesting & 79 & 1.97 & 0.73 & 663 & 2.17 & 0.76 \\
\hline
\end{tabular}

Table 3 describes farmers' off-farm labor supply under different property rights cognition. It can be seen that rural households that think they own the use right and transfer right have the lowest level of off-farm labor supply. With regard to mortgage right, rural households who think they have 
"no rights" have the lowest level of off-farm labor supply, while those who are "uncertain" have the highest level of off-farm labor supply. In the harvesting right, rural households who think the harvesting right is "easy" to apply for have the lowest level of off-farm labor supply, while those who think it is "not too easy" to apply for have the highest level of off-farm labor supply.

Table 3. Farmers' off-farm labor supply under different property rights cognition.

\begin{tabular}{ccc}
\hline Forestland Property Rights & Status & Off-Farm Labor Supply \\
\hline \multirow{3}{*}{ Use } & No rights & 0.57 \\
& Uncertain & 0.52 \\
& Approve consent & 0.51 \\
& Have rights & 0.50 \\
\hline \multirow{2}{*}{ Transfer } & No rights & 0.57 \\
& Uncertain & 0.56 \\
& Approve consent & 0.53 \\
& Have rights & 0.51 \\
\hline \multirow{2}{*}{ Mortgage } & No rights & 0.50 \\
& Uncertain & 0.54 \\
& Approve consent & 0.51 \\
& Have rights & 0.53 \\
\hline \multirow{2}{*}{ Harvesting } & Easy & 0.50 \\
& Not too easy & 0.54 \\
& Difficult & 0.52 \\
\hline
\end{tabular}

\section{Results and Discussion}

\subsection{Effect of Forestland Property Rights on Off-Farm Employment}

Using Stata 14.0 statistical software, this study first compared the Tobit model and double-hurdle model with a likelihood-ratio test. The results showed the likelihood ratio to be 122.71 and the $p$-value as 0.0000 , which indicate that the double-hurdle model is more suitable than the Tobit model for estimating the influence of forestland property rights on off-farm employment.

According to the results displayed in Table 4, within the scope of the forestland property rights, transfer rights passed the test of significance at a $1 \%$ significance level both in its effect on participation in off-farm labor as well as on off-farm labor supply. The pertaining coefficients were positive, which is in line with theoretical expectations. This shows that the more complete the forestland transfer right, the higher the willingness of rural households to participate in off-farm labor, and the higher the degree of off-farm labor supply. This is because forestland use right is the weighted average of the right to transfer the plot to other villagers and the right to transfer the plot to outsiders, which represents the capability of farmers to transfer forestland to others. The transfer right improves the autonomy of rural households to transfer forestland proactively, by reducing the restrictions imposed on them by the forestland. Consequently, this releases the surplus labor in the forest area. Therefore, in the reality of long forestry production cycles, slow return on investment, and the increase in the price difference between forestry production and industrial production in China [61], complete forestland transfer rights contribute to the transfer of rural household labor to off-farm businesses that maximize household income and generate higher revenue to correspondingly increase the degree of off-farm labor. 
Table 4. Estimation results of the impact of forestland property rights on off-farm employment.

\begin{tabular}{|c|c|c|c|c|c|c|}
\hline \multirow{2}{*}{ Variable } & \multicolumn{3}{|c|}{ Participate } & \multicolumn{3}{|c|}{ Supply } \\
\hline & Coef. & Std. Err. & $\begin{array}{c}\mathrm{Z} \\
\text { Value }\end{array}$ & Coef. & Std. Err. & Z Value \\
\hline \multicolumn{7}{|c|}{ Forestland property rights } \\
\hline Use & -0.0706 & 0.3229 & -0.22 & 0.0243 & 0.0286 & 0.85 \\
\hline Transfer & $0.8121^{* * *}$ & 0.3060 & 2.65 & $0.0738^{* * *}$ & 0.0323 & 2.29 \\
\hline Mortgage & -0.3391 & 0.2194 & -1.55 & -0.0234 & 0.0265 & -0.88 \\
\hline Harvesting & 0.3296 & 0.3726 & 0.88 & $0.0712^{*}$ & 0.0407 & 1.75 \\
\hline \multicolumn{7}{|c|}{ Village off-farm environment } \\
\hline Income & 0.3252 & 0.6969 & 0.47 & $0.1427^{*}$ & 0.0700 & 2.04 \\
\hline \multicolumn{7}{|c|}{ Labor characteristics } \\
\hline Male & $-0.7181^{* *}$ & 0.3497 & -2.05 & $0.0720^{*}$ & 0.0379 & 1.90 \\
\hline Age (ln) & $-4.3364^{* * *}$ & 1.1178 & -3.88 & $-0.5501^{* * *}$ & 0.0572 & -9.61 \\
\hline Education & 0.0371 & 0.0313 & 1.18 & $0.0075^{* *}$ & 0.0032 & 2.34 \\
\hline \multicolumn{7}{|c|}{ Family characteristics } \\
\hline Over 70 & $-0.9312^{* * *}$ & 0.3172 & -2.94 & $0.1139^{*}$ & 0.0641 & 1.78 \\
\hline Under 16 & -0.1910 & 0.5186 & -0.37 & 0.0607 & 0.0559 & 1.09 \\
\hline Cadre & $1.1612^{* * *}$ & 0.3057 & 3.80 & $0.0567^{* *}$ & 0.0263 & 2.15 \\
\hline \multicolumn{7}{|c|}{ Forestland characteristics } \\
\hline Area $(\ln )$ & 0.0116 & 0.0645 & 0.18 & $-0.0181^{* *}$ & 0.0080 & -2.24 \\
\hline Plots & 0.0083 & 0.0591 & 0.14 & -0.0063 & 0.0069 & -0.90 \\
\hline \multicolumn{7}{|c|}{ Regional characteristics } \\
\hline Anji & $0.8877^{* * *}$ & 0.2783 & 3.19 & $0.1165^{* * *}$ & 0.0314 & 3.71 \\
\hline Suichang & 0.4426 & 0.3338 & 1.33 & 0.0276 & 0.0292 & 0.95 \\
\hline Chongyi & 0.1072 & 0.2481 & 0.43 & 0.0362 & 0.0257 & 1.41 \\
\hline Con. & $15.7689^{* * *}$ & 4.1982 & 3.76 & $2.0735^{* * *}$ & 0.2599 & 7.98 \\
\hline Wald Chi-squared & \multicolumn{3}{|c|}{$115.05^{* * *}$} & \multicolumn{3}{|c|}{$283.97^{* * *}$} \\
\hline Log pseudo likelihood & \multirow{2}{*}{\multicolumn{3}{|c|}{-147.6183}} & \multicolumn{3}{|c|}{-} \\
\hline Log likelihood & & & & \multicolumn{3}{|c|}{127.2627} \\
\hline Number of obs. & \multicolumn{3}{|c|}{$\overline{742}$} & & 663 & \\
\hline
\end{tabular}

Notes: ***,* and * denote $1 \%, 5 \%$, and $10 \%$ significance level.

Harvesting rights did not show significance in its effect on off-farm labor but did show significance at a 10\% significance level, regarding its effect on off-farm labor supply. The coefficient was positive, meaning that the more complete the forestland harvesting right, the higher the degree of off-farm labor supply. A reason for this may be that rural households' decisions about whether to participate in off-farm labor are mainly affected by the proper disposal of forestland, together with the revenue gap between different labor sectors. Therefore, the negative impact of harvesting rights on participation in off-farm labor was not significant. When rural households have already participated in off-farm labor, the complete harvesting right can reduce the risk of losing forestry revenue. However, due to the long payback period on forestry investment, when farmers are more confident that they can obtain the expected benefits of forestry, farmers will be more assured of their forestland, so they can spend more time on off-farm production [42]. This has promoted the degree of off-farm labor supply. Furthermore, a complete harvesting right can also help rural households plan their planting structure after cutting wood and also contribute to effective improvements within land distribution, further releasing the forestry labor force and promoting the degree of off-farm labor supply.

Neither use right nor mortgage right passed the test of significance in its effect on whether to participate in off-farm labor and off-farm labor supply. This is because the use right represents rural households being able to freely transfer forestland uses and planting, while the peculiarity of forestland means forestry production faces government restrictions all the time. Additionally, forestry has a long production period, resulting in rural households not easily transferring forestland use and 
planting in the short term, even if they think they can freely do so. Thus, use right does not have a significant impact on off-farm employment. As for the mortgage right, this is the right for farmers to act independently to mortgage forestland or trees. Although the mortgage right can provide capital for rural household production, based on this investigation, the popularity of the forest tenure mortgage was very low. In fact, most rural households knew very little about the mortgage right, therefore it has not played a role in promoting investment in forestry production, nor in stimulating rural households' forestry management activities. Therefore, the mortgage right was not a key factor affecting rural households' off-farm employment.

Furthermore, the results shown in Table 4 also reveal that the proportion of off-farm income in the village, which represents the village off-farm environment, did not show significance in its effect on whether to participate in off-farm labor, but did show significance at a $10 \%$ significance level regarding its effect on off-farm labor supply. Moreover, the coefficients were positive. This means that with the increase in the proportion of off-farm income, the degree of off-farm labor supply increases correspondingly. As analyzed above, the proportion of off-farm income in the village impacts the proportion of off-farm income in individual rural households, further impacting the off-farm employment. In other words, when the proportion of off-farm income increases, the proportion of forestland management revenue decreases and rural households will increase their off-farm labor supply to increase their revenue.

As for control variables, in labor characteristics, the proportion of male labor showed significance at a $5 \%$ significance level regarding its effect on whether to participate in off-farm labor with a negative coefficient, and showed significance at a 5\% significance level in its effect on off-farm labor supply with a positive coefficient. The average age of labor showed significance at a $1 \%$ significance level both in its effect on participation in off-farm labor and off-farm labor supply. More so, the coefficients were negative, which means the younger the average age of a laborer, the greater willingness to participate in off-farm labor, and the higher the degree of off-farm labor supply. The average educational level of a laborer showed significance at a 5\% significance level in its effect on off-farm labor supply, and the coefficient was positive, meaning that the educational level significantly increases the degree of off-farm labor supply.

Regarding family characteristics, the proportion of the population over 70 years old showed significance at a $1 \%$ significance level concerning its effect on whether to participate in off-farm labor with a negative coefficient, but showed significance at a $10 \%$ significance level in its effect on off-farm labor supply with a positive coefficient. A possible reason is that rural households with a higher proportion of people over 70 years old are not willing to participate in off-farm labor; but for those rural households that participated in off-farm labor, they will increase the degree of off-farm labor supply to earn more to support more old people. Regarding if families include a village cadre, this characteristic showed significance above the $5 \%$ significance level both regarding its effect on participation in off-farm labor and off-farm labor supply, and the coefficients were positive, showing that village cadre families are not willing to engage in forest production with high risks and a long production period and have more resources to conduct an off-farm labor transfer.

In regard to forestland characteristics, forest area showed significance at a $5 \%$ significance level in its effect on off-farm labor supply, and the coefficient was negative, which means a larger forest area can improve rural households' forestry production activity to some extent, and encourage them to decrease the degree of off-farm labor supply. Lastly, regarding regional characteristics, Anji County showed significance at a $1 \%$ significance level both regarding its effect on whether to participate in off-farm labor and off-farm labor supply, and the coefficients were positive. As Anji County is developing economically at the fastest rate in the investigation region, the whole off-farm employment level was higher. 


\subsection{Regulation Effect of Village Off-Farm Environment on Forestland Property Rights}

Table 5 reports the estimated results after introducing interaction terms of village off-farm environment and forestland property rights. It the decision about whether to participate in off-farm labor, the interaction terms of each forestland right, and proportion of off-farm income in the village failed to show significant results. Regarding off-farm labor supply, the interaction term of transfer right and proportion of off-farm income in the village showed significance at a $1 \%$ significance level, and the coefficient was negative. In addition, the interaction term of the harvesting right and proportion of off-farm income in the village showed significance at a $10 \%$ significance level, and the coefficient was positive. Neither the interaction term of use right and the proportion of off-farm income in the village, nor the interaction term of mortgage right and the proportion of off-farm income in the village, gave significant results. This shows that the increase in the proportion of off-farm income in the village restricts the transfer right's positive incentive in the degree of off-farm labor supply. Rather it strengthens the harvesting right's incentive in the degree of off-farm labor supply.

Table 5. Regulating effect of village off-farm environment on forestland property rights.

\begin{tabular}{|c|c|c|c|c|c|c|}
\hline \multirow{2}{*}{ Variable } & \multicolumn{3}{|c|}{ Participate } & \multicolumn{3}{|c|}{ Supply } \\
\hline & Coef. & Std. Err. & Z Value & Coef. & Std. Err. & Z Value \\
\hline Use & -0.1238 & 0.3357 & -0.37 & 0.0055 & 0.0317 & 0.17 \\
\hline Transfer & $0.7255^{* *}$ & 0.3009 & 2.41 & $0.0846^{* * *}$ & 0.0290 & 2.92 \\
\hline Mortgage & -0.3035 & 0.2287 & -1.33 & -0.0133 & 0.0258 & -0.52 \\
\hline Harvesting & 0.2883 & 0.3937 & 0.73 & $0.0661^{*}$ & 0.0387 & 1.71 \\
\hline Income & 0.1323 & 0.7321 & 0.47 & 0.1235 & 0.0818 & 1.51 \\
\hline Use $\times$ income & -0.0045 & 0.1055 & -0.04 & 0.0034 & 0.0129 & 0.26 \\
\hline Transfer $\times$ income & -0.0387 & 0.0683 & -0.57 & $-0.0284^{* * *}$ & 0.0087 & -3.25 \\
\hline Mortgage $\times$ income & 0.0759 & 0.0981 & 0.77 & 0.0045 & 0.0129 & 0.35 \\
\hline Harvesting $\times$ income & -0.0098 & 0.0751 & -0.13 & $0.0165^{*}$ & 0.0094 & 1.75 \\
\hline Control variable & & Yes & & & Yes & \\
\hline Con. & $16.3751^{* * *}$ & 4.5304 & 3.61 & $2.1091^{* * *}$ & 0.2605 & 8.10 \\
\hline Wald Chi-squared & \multicolumn{3}{|c|}{$123.31^{* * *}$} & \multicolumn{3}{|c|}{$328.25^{* * *}$} \\
\hline Log pseudo likelihood & \multirow{2}{*}{\multicolumn{3}{|c|}{-147.2896}} & \multirow{2}{*}{\multicolumn{3}{|c|}{$\overline{1320070}$}} \\
\hline Log likelihood & & & & \multirow{2}{*}{\multicolumn{3}{|c|}{$\begin{array}{c}132.0070 \\
663\end{array}$}} \\
\hline Number of obs. & \multicolumn{3}{|c|}{742} & & & \\
\hline
\end{tabular}

Notes: ${ }^{* * *}, * *$, and $*$ denote $1 \%, 5 \%$, and $10 \%$ significance level

To further identify the regulating effect of village off-farm environment on forestland property rights, with reference to the method of $\mathrm{Li}$ et al. [62], this paper divides the proportion of off-farm income in the village into 50 equal parts, and calculates the marginal effect of forestland property rights on off-farm employment at each equal point. The results are given in Table 6, which shows that with the increase in the proportion of off-farm income in the village, neither use right nor mortgage right had a significant effect on off-farm labor or off-farm labor supply. The impact of transfer right on participation in off-farm labor first changed from insignificant to significant, and then ultimately turned out to be insignificant. The impact of the transfer right on off-farm labor supply changed from significant to insignificant, and the coefficient gradually became smaller. 
Table 6. Marginal effect of forestland property rights in different village off-farm environments.

\begin{tabular}{ccccccccc}
\hline \multirow{2}{*}{ Equal point } & \multicolumn{5}{c}{ Participate } & \multicolumn{4}{c}{ Supply } \\
\cline { 2 - 8 } & Use & Transfer & Mortgage & Harvesting & Use & Transfer & Mortgage & Harvesting \\
\hline 1 & -0.0107 & 0.1322 & -0.0958 & 0.0494 & -0.0210 & $0.3575^{* * *}$ & -0.0427 & -0.1371 \\
5 & -0.0111 & $0.1256^{*}$ & -0.0879 & 0.0471 & -0.0178 & $0.3250^{* * *}$ & -0.0392 & -0.1129 \\
10 & -0.0116 & $0.1175^{*}$ & -0.0781 & 0.0444 & -0.0139 & $0.2843^{* * *}$ & -0.0348 & -0.0827 \\
15 & -0.0120 & $0.1095^{* *}$ & -0.0686 & 0.0417 & -0.0099 & $0.2437^{* * *}$ & -0.0304 & -0.0524 \\
20 & -0.0125 & $0.1017^{* *}$ & -0.0593 & 0.0391 & -0.0060 & $0.2031^{* * *}$ & -0.0260 & -0.0222 \\
25 & -0.0129 & $0.0941^{* * *}$ & -0.0502 & 0.0366 & -0.0020 & $0.1624^{* * *}$ & -0.0217 & 0.0081 \\
30 & -0.0133 & $0.0867^{* * *}$ & -0.0414 & 0.0341 & 0.0019 & $0.1218^{* * *}$ & -0.0173 & 0.0384 \\
35 & -0.0137 & $0.0795^{* *}$ & -0.0328 & 0.0316 & 0.0059 & $0.0811^{* * *}$ & -0.0129 & $0.0686^{*}$ \\
40 & -0.0141 & $0.0725^{* *}$ & -0.0244 & 0.0293 & 0.0098 & 0.0405 & -0.0085 & $0.0989^{* *}$ \\
45 & -0.0145 & 0.0656 & -0.0162 & 0.0270 & 0.0138 & -0.0002 & -0.0042 & $0.1292^{* *}$ \\
50 & -0.0149 & 0.0590 & -0.0082 & 0.0247 & 0.0177 & -0.0408 & 0.0002 & $0.1594^{* *}$ \\
\hline
\end{tabular}

Notes: $* * *, * *$, and ${ }^{*}$ denote $1 \%, 5 \%$, and $10 \%$ significance level. Only partial results of 50 equal points are shown in the table.

When it comes to participation in off-farm labor, when rural households in a village mainly rely on forestland management revenue, even if the transfer right is complete the importance of forest management revenue impels rural households not to give up forestland easily. When rural households in a village mainly rely on off-farm income, fewer farmers are willing to rent forestland within the village. At the same time, the transaction costs for farmers to transfer forestland to outsiders are relatively high, which has led to the weakening of the transfer right's promotion effect on off-farm employment. With respect to the off-farm labor supply, the increase in the proportion of off-farm income means the complete transfer right is no longer the main reason for rural households releasing more labor. Therefore, the transfer right's incentive effect on off-farm labor supply has been weakened significantly.

Furthermore, the harvesting right had no significant impact on participation in off-farm labor, but the impact on off-farm labor supply changed from insignificant to significant and the coefficient gradually become larger. This means that with the increase in the proportion of off-farm income in the village, the incentive effect of harvesting right on off-farm labor supply has been strengthened. It may be because harvesting rights directly affect the revenue of rural households from forestland management, and the complete harvesting right further assures rural household revenue. Therefore, when the proportion of off-farm income in the village keeps increasing, the increase in off-farm income and certain forestland revenue will further strengthen the positive effect of harvesting right on off-farm labor supply.

\section{Conclusions and Implications}

On the basis of rural household survey data in Zhejiang and Jiangxi provinces in the southern collective forest area, this study analyzed the impact of forestland property rights and village off-farm environment on off-farm employment in the forest region. The empirical results indicated that the complete forestland transfer right promoted decision-making about, and the supply of, off-farm labor by giving transferring rural households forestland autonomy. The complete forest harvesting right significantly increased the supply of off-farm labor by assuring forestland revenue. The off-farm income ratio of the village had a positive effect on the supply of off-farm labor by impacting rural households' family income structure. In addition, under the regulation of village off-farm income ratio, the positive incentives of forestland transfer right on the decision-making about and supply of off-farm labor were gradually weakened, but the incentive effect of forest harvesting rights on the supply of off-farm labor gradually increased.

Based on these conclusions, some policy recommendations can be made. Firstly, the main reform of CFTR should be intensified, the forestland transfer system should be improved, and the forest harvest quota system should be specified. In this way the surplus labor transfer to the non-agricultural sector can be promoted by improving the complete of transfer right and harvesting right, thereby increasing rural households' income in the forest area. Secondly, the implementation of forest tenure mortgage 
loans should be strengthened, loan coverage should be expanded, and policy propaganda should be improved to increase rural households' awareness of forestland mortgage right, provide capital for forestry management, increase farmers' production enthusiasm, and achieve a better allocation of labor resources in the forest area. Thirdly, with the proportion of off-farm income in the village increasing, rural households should be guided to manage cooperatively, while rationally transferring surplus labor in the forest area and encouraging local forestry management talents to take the lead in cooperation to achieve large-scale forestland operations. Last but not least, for those villages with a higher off-farm level, capital from outside can be introduced to manage forestland, thereby decreasing forestland transaction costs, avoiding forestland being abandoned, and promoting forestry production.

The conclusions of this paper are of great significance for the understanding of, and relationship between, forestland property rights and off-farm employment in collective forest areas, also having a certain reference value for the formulation and implementation of China's farmland property rights system. China's farmland property rights system has also undergone many reforms and, in 2013, a new round of farmland property rights certification was launched to clarify farmland ownership. Compared with forestland, the government has enacted fewer restrictions on farmland rights. In response to a large outflow of rural labor, the farmland property rights system should be improved in order to accord farmers complete farmland rights to release surplus labor in the agricultural sector through farmland transfers and scale operations. Additionally, our research conclusions have certain reference significance for the development of agriculture and forestry in other developing regions and countries.

Author Contributions: Y.Y. conceived and designed this study and wrote the introduction and literature reviews. Z.L. wrote the methods, analysis, and discussed the results. A.A.H. and J.L. gave review suggestions on the entire writing process and went through all the sections. H.L. and L.C. gave review suggestions and revised the manuscript. All authors have read and agreed to the published version of the manuscript.

Funding: This research was funded by the National Natural Science Foundation of China, grant number 71603126, 71873099, 71911530164; the Swedish Foundation for International Cooperation in Research and Higher Education, grant number CH2018-7762; and the Humanities and Social Sciences Research Foundation of the Ministry of Education in China, grant number 20YJC630010.

Conflicts of Interest: The authors declare no conflicts of interest.

\section{References}

1. Rozelle, S.; Minggao, S.; Hughart, A.; Giles, J. Leaving china's farms: Survey results of new paths and remaining hurdles to rural migration. China Q. 1999, 158, 367-393. [CrossRef]

2. Du, Y.; Park, A.; Wang, S. Migration and rural poverty in China. J. Comp. Econ. 2005, 33, 688-709. [CrossRef]

3. Huang, J.; Gao, L.; Rozelle, S. The effect of off-farm employment on the decisions of households to rent out and rent in cultivated land in china. China Agric. Econ. Rev. 2012, 4, 5-17. [CrossRef]

4. National Bureau of Statistics (NBS). Report on the Situation of Rural Migrant Workers in 2018; Statistical Publishing House: Beijing, China, 2019.

5. Cai, F. Demographic transition, demographic dividend, and lewis turning point in China. Econ. Res. 2010, 4, 4-13. (In Chinese) [CrossRef]

6. State Forestry and Grassland Administration of China (SFGA). China Forest Resource Report (2014-2018); China Forestry Press: Beijing, China, 2019.

7. National Bureau of Statistics of China (NBSC). National Bureau of Statistics of China Database. 2018. Available online: http://www.stats.gov.cn/ (accessed on 15 November 2019).

8. Hyde, W.; Yin, R. 40 Years of China's forest reforms: Summary and Outlook. For. Policy Econ. 2019, 98, 90-95. [CrossRef]

9. Wei, Y. Report on the situation of rural migrant workers of Zhejiang province in 2018. Zhejiang Econ. 2019, 5, 33-35. (In Chinese)

10. Jiangxi Province Bureau of Statistics of China (JPBSC). Statistical Communique of National Economic and Social Development of Jiangxi Province in 2018. Jiangxi Daily 2019.

11. Xu, J.; White, A.; Lele, U. China's Forest Tenure Reforms-Impacts and Implications for Choice, Conservation, and Climate Change; Rights and Resources Initiative: Washington, DC, USA, 2010. 
12. Yi, Y.; Köhlin, G.; Xu, J. Property rights, tenure security and forest investment incentives: Evidence from China's Collective Forest Tenure Reform. Environ. Dev. Econ. 2014, 19, 48-73. [CrossRef]

13. Liu, P.; Yin, R.; Li, H. China's forest tenure reform and institutional change at a crossroads. For. Policy Econ. 2016, 72, 92-98. [CrossRef]

14. Yang, Y.; Li, H.; Liu, Z.; Hatab, A.A.; Ha, J. Effect of Forestland Tenure Security on Rural Household Forest Management and Protection in Rural China. Glob. Ecol. Conserv. 2020, 22, e00952. [CrossRef]

15. Do, Q.-T.; Iyer, L. Land titling and rural transition in Vietnam. Econ. Dev. Cult. Chang. 2008, 56, 531-579. [CrossRef]

16. Giles, J.T.; Mu, R. Village political economy, land tenure insecurity, and the rural to urban migration decision: Evidence from china. Policy Res. Work. Pap. Ser. 2014, 100, 1-57.

17. Qiu, T.; Luo, B. Does land reallocation negatively affect rural labour migration to non-agricultural sectors? China's Rural Obs. 2017, 4, 57-71. (In Chinese)

18. Potts, D. Rural mobility as a response to land shortages: The caseof Malawi. Popul. Space Place 2006, 12, 291-311. [CrossRef]

19. De La Rupelle, M.; Quheng, D.; Shi, L.; Vendryes, T. Land rights and rural-urban migration in rural China. China Perspect. 2008, 2, 25-35. [CrossRef]

20. Gray, C.L. Environment, land, and rural out-migration in the southern Ecuadorian Andes. World Dev. 2009, 37, 457-468. [CrossRef]

21. Valsecchi, M. Land property rights and international migration: Evidence from Mexico. J. Dev. Econ. 2014, 110, 276-290. [CrossRef]

22. Mullan, K.; Grosjean, P.; Kontoleon, A. Land tenure arrangements and rural-urban migration in China. World Dev. 2011, 39, 123-133. [CrossRef]

23. De La Rupelle, M.; Deng, Q.; Li, S.; Vendryes, T. Land Rights Insecurity and Temporary Migration in Rural China Discussion Paper No. 4668. 2009.

24. Yang, D.T. China's land arrangements and rural labour mobility. China Econ. Rev. 1997, 8, 101-115. [CrossRef]

25. Feng, S.Y.; Heerink, N. Are farm households' land renting and migration decisions interrelated in rural China? NJAS-Wagening. J. Life Sci. 2008, 55, 345-362. [CrossRef]

26. VanWey, L. Land ownership as a determinant of international andinternal migration in Mexico and internal migration in Thailand. Int. Migr. Rev. 2005, 39, 141-172. [CrossRef]

27. De Brauw, A.; Mueller, V. Do limitations in land rights transferability influence mobility rates in Ethiopia? ESSP Work. Pap. 2011, 21, 548-579. [CrossRef]

28. Ma, X.; Heerink, N.; Van Ierland, E.; Shi, X. Land tenure insecurity and rural-urban migration in rural China. Pap. Reg. Sci. 2016, 95, 383-406. [CrossRef]

29. Cheung, S.N.S. The structure of a contract and the theory of a non-exclusive resource. J. Law Econ. 1970, 13, 49-70.

30. Yang, Y.; Li, H.; Xue, C.; Huang, R. Impact of forest property rights and market environment on peasant household forestry investments in different production links in Fujian. Resour. Sci. 2018, 40, 427-438. (In Chinese)

31. Liu, C.; Liu, H.; Wang, S. Has China's new round of collective forest reforms caused an increase in the use of productive forest inputs? Land Use Policy 2017, 64, 492-510. [CrossRef]

32. Démurger, S.; Hou, Y.; Yang, W. Forest management policies and resource balance in China-An assessment of the current situation. J. Environ. Dev. 2009, 18, 17-41. [CrossRef]

33. Besley, T.J.; Ghatak, M. Property Rights and Economic Development. Rev. Soc. Econ. 2009, 39, 51-65.

34. Chen, Z.; Qu, F. The structure of farmland property rights and agricultural performance: A theoretical framework. Acad. Mon. 2006, 38, 87-92. (In Chinese)

35. Jacoby, H.G.; Li, G.; Rozelle, S. Hazards of expropriation: Tenure insecurity and investment in rural China. Am. Econ. Rev. 2002, 92, 1420-1447. [CrossRef]

36. Chen, G.; Liu, Z. Impact of land contract rights on rural labour transfer. China's Rural Econ. 2013, 11, 12-23. (In Chinese)

37. Zhang, X.; Huang, X. Study on the reform of rural land system and the transfer of rural labour force. China Popul. Resour. Environ. 2003, 13, 41-45. (In Chinese) 
38. Zhang, H.; Kuuluvainen, J.; Ning, Y.; Liao, W.; Liu, C. Institutional regime, off-farm employment, and the interaction effect: What are the determinants of households' forestland transfer in China? Sustainability 2017, 9, 1885. [CrossRef]

39. Siikamäki, J.; Ji, Y.; Xu, J. Post-reform forestland markets in China. Land Econ. 2015, 91, 211-234. [CrossRef]

40. Zhou, L.; Zhang, Y.; Dai, G.; Zhang, S. Access to Microloans for Households with ForestProperty Collateral in China. Small-Scale For. 2016, 15, 291-301. [CrossRef]

41. Zeng, W.; Cai, X. Analysis of farmers' willing of forest mortgage loans from the perspective of borrowing demand. Issues Agric. Econ. 2011, 9, 25-30. (In Chinese)

42. He, W.; Zhang, H.; Wang, H. Collective forest tenure reform, structure of property rights and farmer's harvesting behaviour: An empirical analysis based on politics and 415 farming households in 7 counties. China's Rural Econ. 2014, 7, 81-96. (In Chinese)

43. Qin, P.; Carlsson, F.; Xu, J. Forest tenure reform in China: A choice experiment on farmers' property rights preferences. Land Econ. 2011, 87, 473-487. [CrossRef]

44. Niu, Y.; Zhou, J. Transaction costs, farmers' perceptions and participation in the 'agricultural super-docking' behaviour. J. Agrotech. Econ. 2014, 9, 89-96. (In Chinese)

45. Deininger, K.; Jin, S.; Nagarajan, H.K. Efficiency and equity impact of rural land rental restrictions: Evidence from India. Eur. Econ. Rev. 2008, 52, 892-918. [CrossRef]

46. Chen, Z. The Structure of Farmland Property Rights and Agricultural Performance: An Empirical Study on China in Transition. Ph.D. Thesis, Nanjing Agricultural University, Nanjing, China, 2005. (In Chinese).

47. Liu, Y.; Yao, S.; Lin, Y. Effect of Key Priority Forestry Programs on off-farm employment: Evidencefrom Chinese rural households. For. Policy Econ. 2018, 88, 24-37. [CrossRef]

48. Cragg, J.G. Some statistical models for limited dependent variables with applications to the demand for durable goods. Econometrica 1971, 39, 829-844. [CrossRef]

49. Hennessy, T.C.; Rehman, T. Assessing the impact of the decoupling reform of the common agricultural policy on Irish farmers' off-farm labour market participation decisions. J. Agric. Econ. 2008, 59, 41-56. [CrossRef]

50. Van Gelder, J.L. What tenure security? The case for a tripartite view. Land Use Policy 2010, 27, 449-456. [CrossRef]

51. Ma, X.; Heerink, N.; Van Ierland, E.; van den Berg, M.M. Land tenure security and land investments in northwest China. China Agric. Econ. Rev. 2013, 5, 281-307. [CrossRef]

52. Holden, S.T.; Xu, J.; Jiang, X. Tenure security and investment effects of forest tenure reform in China. In Land Tenure Reform in Asia and Africa: Assessing Impacts on Poverty and Natural Resource Management; Holden, S.T., Otsuka, K., Deininger, K., Eds.; Macmillan: New York, NY, USA, 2013; pp. 256-282.

53. Zhang, Y.; Song, W. Study on the impact of forest tenure system reform on forest resources in collective forest areas. J. Agrotech. Econ. 2012, 4, 96-104. (In Chinese)

54. Cheng, M.; Pan, X. Empirical analysis on the effects of individual features and family traits to non-farm employment. China Popul. Resour. Environ. 2012, 22, 94-99. (In Chinese)

55. Zhang, J. Continue to Deepen Reform of Collective Forest Rights System, Comprehensively Improving Collective Forestry Development. For. Econ. 2016, 1, 3-8. (In Chinese)

56. State Forestry and Grassland Administration of China (SFGA). Three highlights of deepening the reform of collective forest rights system in Jiangxi Province. 2010. Available online: http://www.forestry.gov.cn/ (accessed on 18 March 2020).

57. Anji County Bureau of Statistics of China, Anji Investigation Team of National Bureau of Statistics of China (ACBSC). Anji Statistical Yearbook; China Statistics Press: Beijing, China, 2018.

58. Lishui Municipal People's Government of China (LMPGC). Various data of forest resources in Suichang County are among the top in the province. 2018. Available online: http://www.lishui.gov.cn/zfzx/tpxx/ 201910/t20191012_4147227.html (accessed on 20 November 2019).

59. Chongyi County Bureau of Statistics of China, Chongyi County People's Government of China (CCBSC). Statistical Communique of National Economic and Social Development of Chongyi County in 2018. 2018. Available online: http://www.chongyi.gov.cn/xxgk/tjxx/201904/t20190401_996998.html (accessed on 21 November 2019).

60. Suichuan County People's Government of China (SCPGC). Overview of Suichuan County (2018). Available online: http://www.suichuan.gov.cn/doc/2019/06/10/36577.shtml (accessed on 21 November 2019). 
61. Liu, Z.; Zhang, T.; Yu, J.; Zhou, L. Determinants of rural households' afforestation program participation: Evidence from China's Ningxia and Sichuan provinces. Glob. Ecol. Conserv. 2019, 17, e00533. [CrossRef]

62. Li, N.; He, W.; Qiu, T.; Chen, L. Farmland Property Right Structure, Production Factor Efficiency and Agricultural Performance. Manag. World 2017, 3, 44-62. (In Chinese)

(C) 2020 by the authors. Licensee MDPI, Basel, Switzerland. This article is an open access article distributed under the terms and conditions of the Creative Commons Attribution (CC BY) license (http://creativecommons.org/licenses/by/4.0/). 